\title{
The demise of the INF Treaty: a path dependence analysis
}

DOI: http://dx.doi.org/10.1590/0034-7329202100202

Rev. Bras. Polít. Int., 64(2): e002, 2021

Revista Brasileira de Política Internacional ISSN 1983-3121

http://www.scielo.br/rbpi

\section{Augusto C. Dall'Agnol'1}

${ }^{1}$ Universidade Federal do Rio Grande do Sul - Departamento de Economia e Relações Internacionais, Porto Alegre, RS, Brazil

(augusto.dallagnol@ufrgs.br)

iD ORCID ID: orcid.org/0000-0002-6658-4470

\section{Marco Cepik ${ }^{2}$}

2Universidade Federal do Rio Grande do Sul - Departamento de Economia e Relações Internacionais, Porto Alegre, RS, Brazil

(marco.cepik@ufrgs.br)

\section{Copyright:}

- This is an open-access article distributed under the terms of a Creative Commons Attribution License, which permits unrestricted use, distribution, and reproduction in any medium, provided that the original author and source are credited.

- Este é um artigo publicado em acesso aberto e distribuído sob os termos da Licença de Atribuição Creative Commons, que permite uso irrestrito, distribuição e reprodução em qualquer meio, desde que o autor e a fonte originais sejam creditados.
Received: March 09 ${ }^{\text {th }}, 2021$ Accepted: May 11 $1^{\text {th }}, 2021$

This article explains changes in strategic stability through a path dependence framework, discussing its antecedent conditions, increasing returns, cleavages, critical junctures, reactive sequences, and legacy. We identify the leading causes of its formation, reproduction, modification, and, eventually, its end. Such an analysis is relevant as far as we observe significant changes in cornerstone's aspects of strategic stability after the abrogation of the ABM Treaty and the INF Treaty. We argue that strategic stability as an institution passes through radical modifications produced by reactive sequences breaking the causal loop that allowed its reproduction since its formation.

Keywords: Arms control; INF Treaty; nuclear age; path dependence; strategic stability.

\section{Abstract}


2006). To explain the INF Treaty's demise, one needs to understand the causes and consequences of institutional pathways as they interact with military power relations and capabilities (Wivel and Paul 2019).

This article makes an original contribution to this special issue by explaining strategic stability as a critical informal international institution through a path dependence framework. It advances the agenda of path dependence analysis employed in Political Science, Historical Sociology, and Economics into the interdisciplinary field of International Relations (Fioretos 2017; Rixen and Viola 2016). We aim at contributing to the debate by analyzing informal institutions and power dynamics not as alternative explanations. ${ }^{2}$

First, by integrating power and institutions within the same framework, the article "departs from the realist-institutionalist debates that often exaggerate the divide" (Carson and Thompson 2019, 102). Second, it avoids the normative-prescriptive stance that sometimes embodies institutionalist analysis (Ikenberry 2018). Third, it allows one to understand institutional changes within a path dependence framework (Hanrieder and Zürn 2017; Fioretos 2011; Rixen and Viola 2016). Hence, it contributes to the Historical Institutionalism challenge to "avoid letting an emphasis on explaining continuity foreclose the possibility of accounting for change" (Keohane 2017, 323). Finally, our analysis provides a new approach that binds together path dependence explanatory power with prospective reasoning to construct future scenarios (Schoemaker 2020).

We locate strategic stability in a path dependence framework by discussing its antecedent conditions, increasing returns, cleavages, critical junctures, reactive sequences, and legacy (Bennet and Elman 2008; Capoccia and Kelemen 2007; Collier and Collier 1991; Mahoney 2000). Our central argument is that strategic stability is an "internally based international security institution" (Duffield 2006) that is passing through significant modifications caused by political and strategic disputes (2001-2021). These modifications are favored by reactive sequences that have broken the causal loop allowing its reproduction since its formative and reproductive periods (1968-2001). As a result, we are witnessing a self-undermining process of institutional change (Greif and Laitin 2004).

Despite the five-year extension of the New START proposed by President Joe Biden on February 2021, the current situation is precarious. First, the counter-intuitive U.S. revisionism towards its own liberal international order was not inaugurated by Donald Trump. As Jervis (2006) notes, the irony is the U.S. seeks to change those rules at least since G.W. Bush's presidency, mostly influenced by Dick Cheney and Donald Rumsfeld. Second, issues regarding arms control and limitation are subject to both partisan and executive-legislative dynamic struggles, not to mention recurring cleavages among foreign policy elites (Bose et al. 2019; Sapolsky et al. 2008).

The first and major assault on the arms control regime was the U.S. unilateral abrogation of the ABM Treaty on December 2001. In a sequential move, Russia notified other signatories

\footnotetext{
2 Freyber-Inan $(2019,187)$ points to the importance "to relax the focus on formal institutions to understand that power also operates through and is constrained by informal institutions, unwritten rules, and norms."
} 
of its intended suspension of the CFE Treaty on July 2007. More recently, on October 2018, the U.S. announced its intention to withdraw from the INF Treaty, effectively doing so on August 2019. On November 2020, the U.S. formally withdrew from the Open Skies Treaty. As for the multilateral nuclear regime, suffice it to mention that, since the Non-Proliferation Treaty (NPT) signature in 1968, India, Pakistan, Israel, and North Korea became nuclear-armed states. Finally, the Treaty on the Prohibition of Nuclear Weapons (TPNW), which entered into effect on January 2021 , is a critical initiative. Still, no nuclear-armed state signed it.

We argue that bilateral strategic arms control was already at risk before the INF Treaty collapse. The extension of New START has not restored it. However, in the second nuclear age, the INF Treaty's demise is particularly relevant. Reagan and Gorbachev signed the INF Treaty in 1987 to eliminate nuclear and conventional ground-launched ballistic and cruise missiles with ranges between 500 and 5,500 kilometers. The treaty mandated on-site inspections at nuclear installations, paving the way for deep cuts in strategic forces. Whether nuclear or conventionally armed, INF-class missiles are destabilizing because they can reach their targets within ten minutes with little or no warning. They raise the specter of miscalculation in a crisis and increase national insecurity. Hence, "developments resulting from the second nuclear age have prompted states to undertake actions which effectively undermine expressed policy goals" (Garcia 2017, 356).

It is worth mentioning two complacent views about the United States' role in the eroding nuclear weapons control regime. The first view argues that Washington should make efforts "to bring Russia back to compliance with the INF Treaty" or, even, to expand the treaty to China (Ghoshal 2016). In sum, it is against the treaty's abrogation but accepts the official reasoning about Russia's failure to comply. The second view considers the decision to exit the treaty correct regardless of specific compliance breaches. It perceives the arms race as an inevitable feature of the following decades and the need for the U.S. to act preemptively (Kroenig 2018).

The remainder of this text is organized as follows. First, we demonstrate why and how strategic stability shall be considered an institution. Second, we discuss strategic stability within a path dependence framework, from the antecedent conditions to the critical juncture that alters the status quo ante. Third, we describe the new, unstable strategic context's legacy reproduction mechanisms. Finally, we present three possible future scenarios, combining explanatory and prospective reasoning.

\section{Strategic stability as institution and power}

The demise of the INF Treaty is embedded in a broader international governance crisis. Since historical institutionalism considers "global governance as a sticky and complex institutional field" (Hanrieder and Zürn 2017, 93), it well fits our purposes in this analysis. Second, the current scenario of an unveiling instability between nuclear powers presents itself as a significant change in the realm of international security. Since its formation phase, the arms control regime has 
never suffered such a setback. Third, while the $9 / 11$ event sets the dawn of the 21 st century for various analyses, we focus on the U.S.'s unilateral abrogation of the ABM Treaty, since it has set in motion distinct security dynamics.

Against this backdrop, arms control failures and revisionist nuclear postures have direct implications to the triangular relations between the U.S. (Brown 2018; Cimbala 2018; Lonsdale 2019; Péczeli 2018), Russia (Trenin 2019), and China (Chase 2018; Wang 2018). International strategic stability is based on each part's inability to carry out a first attack capable of disabling most, if not all, nuclear forces that other states would use in a retaliatory attack. As Koblentz $(2014,19)$ puts it, the "essence of strategic stability is limiting the incentives for states to launch a first strike while at the same time increasing their confidence that they will be able to launch a second."

Arms control regimes intend to reduce risks and increase predictability by managing quantities and classes of weapons and their uses. Hence, they are products of their respective "geopolitical context, and typically accompany a broader easing in tensions or a rapprochement" (IISS 2020, 61-62). The nuclear arms control regime included, among others, the ABM Treaty (1972), the Intermediate-Range Nuclear Forces Treaty (INF) signed in 1987, the Conventional Armed Forces in Europe (CFE) Treaty (1990), the Open Skies Treaty (1992), and the New Strategic Arms Reduction Treaty (New START) signed in $2010 .^{3}$

Nevertheless, three main features characterize the "second nuclear age" (Garcia 2017; Koblentz 2014). ${ }^{4}$ First, the diminishing role of treaties and the near-collapse of the nuclear arms control regime between the U.S. and USSR/Russia since the late 1960s. Second, the development of new military technologies, such as hypersonic weapons, ${ }^{5}$ related to the U.S.'s third offset strategy and the Russian and Chinese responses to it (Acton 2017; Dombrowski 2015; Wilkening 2019). Third, nuclear-armed states now face two or more potential adversaries. Multiple threats and vulnerabilities generate "security trilemmas," where "changes in one state's nuclear posture or policy can have a cascading effect on the other nuclear-armed states" (Koblentz 2014, 3).

These three features are making the second nuclear age more unstable. Strategic stability shall be treated as an institution as its formal and informal rules create predictable patterns of collective action among states, even when they have divergent preferences and interests. It is mostly (but not entirely) an informal type of institution (Fioretos 2017).

Three additional comments are required. First, "institutions rest on a set of ideational and material foundations that, if shaken, open possibilities for change" (Thelen 1999, 397). Nevertheless, policies may become self-reinforcing and resist alteration, providing incentives that encourage actors to behave in such a way as to lock into existing modes (Longhurst 2003). Second,

\footnotetext{
3 For further discussion, see Jervis (1993) and Baylis (2002).

4 We follows Garcia's (2017) and Koblentz's (2014) designation of "second nuclear age," instead of Gray's (1999) and Naylor's (2019) "third nuclear age."

5 Those are "a new class of threat because they are capable both of maneuvering and of flying faster than 5,000 km/hr. Their function is to penetrate missile defenses and to further compress the timelines for a response by a nation under attack" (Speier et al. 2017, 47).
} 
international institutions may become international regimes (Keohane 1988, 4). According to Young $(1982,277)$, social regimes, as all social institutions, "are recognized patterns of behavior or practice around which expectations converge." Onuf $(2013,13)$ even argues "the two terms [regimes and institutions] are indistinguishable."

Third, "knowing how institutions were constructed provides insights into how they might come apart" (Thelen 1999, 400). Yet, one should avoid focusing excessively on continuity and stability maintenance. As Cepik and Ambros $(2014$, 527) put it, despite "the presence of concepts such as critical junctures, conflicts, and regime breakdown, permanence plays a much bigger role than discontinuity within this [path dependence] approach". 6 Similarly, Weyland $(2008,281)$ points out "the need to rethink institutionalist approaches, whose static and linear assumptions make it difficult to account for profound political change." Hence, scholars should pay greater attention to the specific mechanisms that sustain such self-reinforcing sequences.

From a social perspective, power politics is part of international institutions' creation and evolution (Wivel and Paul 2019). Strategic stability as an institution is defined by each side's inability to carry out a first attack capable of disabling most, if not all, nuclear forces that the other state would use in a retaliatory attack (Glaser 2010; Kokoshin 2011). Strategic stability breaks down or enters into crisis when the settled rules and arrangements are thrown into dispute or when the forces that perpetuate order no longer operate (Ikenberry 2014). Wivel and Paul $(2019,3)$ note that "Institutions can decline or lose their strength, in particular when major powers violate the norms, principles, and rules inherent in them or engage in self-seeking policies that ignore them."

Therefore, the development of new technologies affects strategic stability in different ways, including changing the incentives various actors have to uphold or abandon treaties, such as the INF Treaty. As Gray $(1990,12)$ argues, the "discussion of weaponry abstracted from considerations of policy and strategy amounts to a crude reductionism." The crucial point is that the survival of a country's nuclear arsenal depends on uncertain technological change and opponents' efforts to develop new technologies. Hence, states may feel compelled to arms races to ensure that their deterrent forces will have the ability to survive against their adversaries' counter-forces capabilities (Lieber and Press 2017). The development of new weapons may also affect strategic stability. Hypersonic missiles, for example, "reduce warning time and might inhibit a state's ability to retaliate against a nuclear first strike. These technologies will increase pressure on both crisis escalation and incentives for arms racing" (IISS 2020, 62). Since national governments fear falling behind when disruptive new technologies emerge and undermine their deterrent forces, ongoing arms control and related institutions, such as strategic stability, are affected by the decisions to invest and employ such technologies more offensively or defensively. As the leading great power

\footnotetext{
6 Cepik and Ambros (2014) apply punctuated equilibrium theory to study change and discontinuity in security institutions. Nevertheless, we understand that they are not mutually exclusive explanations, since "critical junctures, like the notion of punctuated equilibrium, imply a model of change in which long periods of stasis are disrupted by short bursts of change which are followed again by long periods of path dependence" (Rixen and Viola 2016, 13).
} 
in military terms, when the U.S. develops new capabilities (nuclear and enabling technologies), in conjunction with decisions to abandon the formal pillars of strategic stability as an institution, these actions set in motion a complex interactive process.

The convergence of new military technologies challenges and the declining importance of treaties affect strategic stability. This particular combination of factors might produce instability and insecurity that can be better understood using path dependence analysis. This type of research allows scholars to explicitly understand the formation, reproduction, and transformation of strategic stability.

\section{Nuclear strategic stability as a path dependent process}

As an institution, strategic stability creates predictable patterns of collective action among states even when they have divergent preferences and interests (Betts and Collier 2017). The term "strategic stability" was broadly defined in the Joint US-USSR Statement (1990) as a balance of strategic forces of the USSR and the U.S. where there were no incentives for a first strike (Kokoshin 2011).

Its antecedent conditions refer to the previous period when both USSR and U.S. had great incentives for developing technologies and strategies to achieve a first disarming strike capability. This period goes from the beginning of the nuclear revolution and U.S. monopoly to the period of nuclear parity (Betts 1986). After both countries developed second-strike retaliatory capabilities, their governments converged on a set of interdependent principles encapsulated in strategic stability, mainly mutual vulnerability and employment of nuclear weapons as an ultima ratio deterrent. These principles took shape during the 1960s and 1970s in the first nuclear age, organized and dominated by the rivalry between two superpowers (Garcia 2017; Gray 1999). The early institutionalization developed between the Treaty on the Non-Proliferation of Nuclear Weapons (1968) and the Anti-Ballistic Missile Treaty (ABM) (1972). As Naylor (2019, 277) describes it, through a "series of arms control agreements and nuclear crisis management, the two great powers have arguably 'settled' on nuclear force capabilities and postures that maintain strategic stability."

Two crucial milestones were the ABM Treaty and the Strategic Arms Limitation Talks I (SALT I) of May 1972. Taking into consideration those arms limitation treaties, plus the SALT I Protocol (1974) and the SALT II tentative agreement (1979), the expected possibility of surviving a thermonuclear war was reduced, and stability was forged out of mutually assured destruction (MAD). One may also add the INF Treaty (1987) and the Strategic Arms Reduction Treaty (1991) as reinforcing parts of the institutional dimension of strategic stability.

In short, strategic stability as an institution results from both material (second-strike capability) and normative ${ }^{7}$ factors (treaties) that exhibited self-reinforcing sequences, or increasing

Hanrieder and Zürn (2017) trace the distinction between "material" and "normative" mechanisms. 
returns, from 1972 to 2001. Nevertheless, material factors, or the impossibility of a successful first strike by both sides, precedes arms control treaties, not the other way around. The order of events - that is, sequence - affects how things happen in institutional reproduction or change (Mahoney 2000).

Strategic stability as an institution also has norms and procedures adopted in joint agreements rendering collective results. And efficient institutions reinforce strength, preserving its normative structure, turning any other path of change dependent on this pre-established structure (North 1993). In a path-dependent analysis, it is called increasing returns, which means that the probability of taking one step forward in the same established path increases every time that it moves in the same set path. That occurs because the benefits of the current activity, compared to other possible options, increase over time. What one may observe then is the self-strengthening process of a pattern or the stable reproduction of a particular result over time. ${ }^{8}$

Any bids for achieving first strike capacity represent cleavages that may disrupt strategic stability. In short, cleavages - or crisis - "emerges out of the antecedent conditions and in turn triggers the critical juncture" (Collier and Collier 1991, 30). However, not every attempt will disrupt the causal loop and trigger a critical juncture. For instance, President Reagan announced the Strategic Defense Initiative (SDI) on March, 1983. Its intended goal was to deny other states second-strike capacity and therefore render MAD obsolete. The SDI was characteristic of a period of renewed ideological and political polarization, both inside the U.S. and between the two superpowers. Throughout the 1980s, the U.S. government funded research and development of an array of weapons systems (including direct energy and anti-satellite), as well as advanced command and control-enabling systems. However, due to the immaturity of the required technologies and the Soviet Union's decision under Gorbachev to engage in direct negotiations with the U.S., the previous nuclear treaties were upheld, and new ones were signed reducing warheads and missiles (including the INF in 1987 and the START I in 1991). Nuclear strategic stability even survived the collapse of the Soviet Union in 1991. The combination of an assured nuclear second-strike capability and the formal regulations inscribed in bilateral treaties allowed for self-reinforcing sequences of stable strategic interactions. At least for some time.

In the ensuing years after winning both the Cold War and the Gulf War (1991), economic and ideologically self-confident, the U.S. grew more ambitious regarding its place in the new world order. On the one hand, the United States sought to combine engagement with China and the harsh containment of a weakened Russia. Rewards (supporting China into the World Trade Organization) and punishments (NATO's expansion into Eastern Europe) were majestic and full of consequences. Since 1993, when the Bill Clinton government established the Ballistic Missile Defense Organization (BMDO), Washington began to develop new anti-ballistic missile

\footnotetext{
8 Mahoney $(2000,535)$ observes that "In the case of a self-reinforcing sequence, the contingent period corresponds with the initial adoption of a particular institutional arrangement, while the deterministic pattern corresponds with the stable reproduction of this institution over time. By contrast, in the case of a reactive sequence, the contingent period corresponds with a key breakpoint in history, while the deterministic pattern corresponds with a series of reactions that logically follow from this breakpoint."
} 
capabilities. Nevertheless, there is a negative relation between anti-ballistic missile defenses and strategic stability (Ivanov 2000; Kokoshin 2011). Mainly, because it requires strong offensive capabilities to intercept and destroy another country's ballistic missiles along with their space and ground network of enabling capabilities, such "defenses" could incite a preemptive first strike from a country that believes its defenses could protect it from the massive retaliation of the other part (Ford 2013; Harvey 2003).

On December 2001, the U.S. unilaterally abrogated the ABM Treaty. This cleavage set a different path because it undermined one of the main formal foundations of the reproduction mechanism of strategic stability. Different from the SDI, the current cleavage resulted in a critical juncture. In other words, cleavages are "tensions that lead up [or not] to the critical juncture" (Collier and Collier 1991, 32). The ABM Treaty's abrogation inaugurates material and formal reactive sequences. However, "change is not a necessary element of a critical juncture" (Capoccia and Kelemen 2007, 352). Naylor (2019) argues that China is provoking a multipolar competition capable of disrupting strategic nuclear stability. However, the U.S. decision to unilaterally abrogate the ABM Treaty was taken much earlier and was supported by material capabilities and geopolitical ambitions.

Critical junctures may result in significant changes, usually combining revolutionary technological innovation and institutional reforms. Such periods of change develop new mechanisms of legacy production and reproduction. A series of intervening steps mold the legacy of critical junctures. Through them, the legacy's reproduction is sustained by interactive political decisions, new behavior and attitudes, and emerging institutions (Collier and Collier 1991). Critical junctures are disruptive moments that may change preexistent institutional arrangements and norms. As Pierson (2000, 265) states, incremental change continues "until something erodes or swamps the mechanisms of reproduction that generate continuity." Besides being an essential central element concept of historical institutionalism (Capoccia and Kelemen 2007), critical juncture brings an element of dynamism while assessing institutional development "as these are moments of relative structural indeterminism in which agency matters and choices are possible" (Rixen and Viola 2016, 13).

The abrogation of the ABM Treaty was a conscious effort by the U.S., although never explicitly recognized, to achieve nuclear primacy (Lieber and Press 2006). Thus, the critical juncture may be located in 2001, and its legacy remains until now. It is worth mentioning at least two mechanisms of production of the legacy and the destabilization we identify with the main features of the second nuclear age (Figure 1).

Figure 1. Periodical division

\begin{tabular}{|c|c|c|c|c|c|c|}
\hline \multicolumn{4}{|c|}{ First Nuclear Age (1945-1991) } & \multicolumn{3}{|c|}{ Second Nuclear Age (1991-2021) } \\
\hline Un & ble & Stabilization & Stable & Stable & Destabilization & Unstable \\
\hline 1945 & 1968 & 1972 & 1991 & 2001 & 2003 & 2021 \\
\hline
\end{tabular}

Source: Authors' elaboration 
First, there has been the development of ABM defenses since 2001. Albeit carried with interruptions and counter-movements by Russia and China, it may be considered a continuum task of the United States' governments after 2001. Second, the development of the Conventional Prompt Global Strike (CGPS) concept, mainly since January 2003. In other words, in the second nuclear age, "conventional platforms can more credibly target and destroy well-protected nuclear forces, thus undermining nuclear deterrent capabilities of a state without the use of nuclear weapons" (Garcia 2017, 350). In brief, "The entanglement of non-nuclear weapons with nuclear weapons and their enabling capabilities is exacerbating the risk of inadvertent escalation" (Acton 2017, 1).

The CGPS official justification is the need to provide a preventive defense against deliberate or accidental attacks without crossing the nuclear threshold (Cepik and Santos 2017). In short, it aims to allow the United States to strike targets in any place on Earth with conventional weapons in less than an hour, without resorting to expeditionary forces. However, once a country seeks to use conventional weapons to destroy their opponents' strategic nuclear weapons, "the role of conventional weapons also has to be taken into account to access strategic stability" (Dvorkin 2012, 29).

New technologies of high-precision-guided weapons directly contribute to disrupting strategic stability (Bruusgaard 2016; Kashin and Raska 2017; Rojansky 2013). Any increased tolerance towards tactical nuclear weapons would also reinforce the same problem. As Lonsdale (2019, 107) notes, the "expansion role of nuclear weapons has raised concerns about stability, blurring the distinction between conventional and nuclear forces, and lowering the threshold for nuclear use.” The 2018 NPR also calls for integrated nuclear and non-nuclear strategies and operations specifically against Russia and China (Peters et al. 2018). A clear distinction between nuclear and non-nuclear warfare, and the ability to signal that such a threshold is not being crossed, is in jeopardy. According to Brown $(2018,278)$, "this [Trump] administration appears to be embracing capabilities and strategies which blur that distinction."

The development of ABM defenses and the CGPS concept and capabilities are mechanisms of production of the legacy following the 2001 critical juncture. Both seek to allow the U.S. to destroy intercontinental ballistic missiles (ICBM) on its hardened concrete silos. Neither Russia nor China sat still since 2001, to mention only the two other great powers with second-strike capabilities. Their reactions and the American reactions to their actions and declarations indicate that nuclear primacy was not achieved. Therefore, the mechanisms of reproduction of the legacy are still in motion.

\section{Strategic instability as legacy reproduction}

Mechanisms of reproduction contribute to perpetuating the legacy of the critical juncture through successive processes and political-institutional decisions. They occur when the legacy 
is no longer an automatic result (Collier and Collier 1991). The point is that achieving nuclear primacy also affects the other parts of this institution (Acton 2013). In other words, "the efforts of any one or number of states to achieve strategic primacy over another, [...] will inevitably set off a chain reaction that will undermine the process" (Garcia 2017, 355). The instability legacy produced in 2001 has been reproduced by the interactions between great powers.

For example, one may point to Putin's speech in 2018 on the development of Russia's new hypersonic weapons designed to penetrate any existent missile defense. Putin made it clear that this kind of weapon development directly responds to the unilateral abrogation of the ABM Treaty by the United States. China has also been concerned about the threat that a U.S. multilayered missile-defense system poses to its retaliatory capacity in a crisis (Koblentz 2014). Hence, "China is developing medium- and intermediate-range ballistic and cruise missiles equipped with countermeasures to evade the enemy ballistic missile defense systems" (Ghoshal 2016, 366). 9 At the same time, the U.S. military bet on hypersonic technologies to overcome "an adversary's A2/AD capabilities" (Naylor 2019, 183). ${ }^{10}$

The same endeavor is evident in Russia since the 2008 military reform. Russian new hypersonic capabilities may be a useful bargaining chip in future arms-control negotiations. For example, "Medvedev and his predecessor-successor Putin have made it clear that Russia's geostrategic perspective links U.S. and NATO missile defenses to cooperation on other arms-control issues" (Cimbala and McDermott 2015, 95). In moments when the conventional rules are under attack, great powers will fear the risks of falling behind. The advances in the computer revolution may turn nuclear forces more vulnerable than before, and some states might have more difficulty protecting their arsenals as orientation systems, sensors, data processing, communication, artificial intelligence, and a series of other products of the computer revolution remain to advance (Lieber and Press 2017).

In short, the mechanisms of reproduction of the instability legacy relate to the great powers' efforts to develop new technologies that are detrimental, in the short term, to strategic stability. The U.S. seeks to obtain nuclear primacy, while Russia and China want to preserve their deterrence capabilities. New military technologies not directly or immediately associated with such incompatible strategic goals, such as conventional weaponry, cyber, or space capabilities, become sources of additional instability - particularly in contested zones and during regional crises. To deny other states the ability to disarm one's retaliatory strike capacity with a first strike, more aggressive postures and additional defensive and offensive capabilities are required. These legacy reproduction mechanisms further undermine strategic stability as the three great powers try to guarantee a most advantageous position when the time comes to lock in new institutional arrangements. As a result, we are witnessing the decay of a self-undermining institution (Hanrieder and Zürn

\footnotetext{
9 See also Glaser and Fetter (2016), Koblentz (2014) and Chase, Garafola and Beauchamp-Mustafaga (2018).

10 Wilkening $(2019,129)$ puts that "The principal rationale for developing similar weapons in the United States is to hold Russian and Chinese mobile targets at risk and to improve the ability to penetrate advanced integrated air-defence systems."
} 
2017). ${ }^{11}$ Rixen and Viola $(2016,12)$ argue that path undermining is "the process by which a choice, decision, or event leads to decreasing returns to a certain behavior or rule, leading to the unravelling of the institution."

\section{Three possible scenarios: Il buono, il cattivo, il brutto}

It is difficult to foresee the end of the critical juncture's legacy. The results of such a strategic competition are contingent and not predetermined. It is not possible to know beforehand who will benefit the most from the technological innovations and political maneuvers. Nevertheless, at least three paths towards the near future can be outlined as prospective scenarios.

The first and most optimistic scenario (il buono) foresees a prompt renewal of arms-control efforts as an immediate result of New START's extension and Biden's election. Such cleavage in the current path of strategic destabilization would allow for a brand new common understanding surrounding strategic stability - much in line with the U.S.-Russian reset back in 2010 or a G-2 (U.S.-China) special relationship.

Hence, it would have the settlement of political and strategic grievances in its core, probably with the maintenance and strengthening of the existing strategic talks. Although it would soften current instabilities, it might, at best, restore strategic stability based upon MAD as an alternative to nuclear weapons abolition as mandated by the new TPNW. Such would be the case if critical juncture would not result in revolutionary institutional change (Capoccia and Kelemen 2007, 352).

The second possible scenario (il brutto) relates to the continuing growth of entropy before great powers find a lower common ground to return to arms-control talks. It carries implications that go further than liberal institutionalism and purely realist arguments. One would observe an initial growth of strategic instability followed by a gradual return to strategic stability. Such instability would be motivated by the dynamics of balance of power and the risks of falling behind. Great powers would make efforts to take all advantages of technological innovations to be in a better position when the time comes to lock in future configurations of power. That means that they probably will not self-contain, leading to potential crises. Nevertheless, the disruptive costs associated with such competition (and local escalation towards direct armed clashes) could gradually dampen the incentives for a never-ending arms race.

\footnotetext{
11 Hanrieder and Zürn $(2017,94)$ recognize that self-undermining mechanisms come close to Mahoney's (2000) reactive sequences. Keohane $(2017,328)$ points out the same conceptual similarity. In brief, these concepts involve institutional decline.
} 
Figure 2. Three hypothetical scenarios

\begin{tabular}{|c|c|c|c|}
\hline & Scenario A (Good) & Scenario B (Ugly) & Scenario C (Bad) \\
\hline Main characteristic & $\begin{array}{c}\text { Prompt renewal of } \\
\text { arms-control efforts as an } \\
\text { immediate result of New } \\
\text { START's extension }\end{array}$ & $\begin{array}{l}\text { Entropy continues to grow } \\
\text { higher before great pow- } \\
\text { ers find common ground } \\
\text { to return to arms-control } \\
\text { talks }\end{array}$ & $\begin{array}{c}\text { Intense and lengthy } \\
\text { struggle between great } \\
\text { powers over advantages of } \\
\text { cutting-edge technologies }\end{array}$ \\
\hline Result & $\begin{array}{c}\text { Return to strategic stabil- } \\
\text { ity and the settlement } \\
\text { of political and strategic } \\
\text { grievances }\end{array}$ & $\begin{array}{l}\text { Initial growth of strategic } \\
\text { instability followed by a } \\
\text { gradual return to strategic } \\
\text { stability }\end{array}$ & $\begin{array}{c}\text { Growing political and } \\
\text { strategic animosity and } \\
\text { "lock-in" of strategic in- } \\
\text { stability }\end{array}$ \\
\hline Causes & $\begin{array}{l}\text { Possibility of achieving a } \\
\text { shared understanding of } \\
\text { strategic stability }\end{array}$ & $\begin{array}{l}\text { Risks of falling behind } \\
\text { and the disruptive costs of } \\
\text { competition }\end{array}$ & $\begin{array}{c}\text { Efforts to achieve strategic } \\
\text { primacy and its responses } \\
\text { at the global and regional } \\
\text { levels }\end{array}$ \\
\hline Plausibility & Low & High & Medium \\
\hline Criticality & Low & Medium & High \\
\hline
\end{tabular}

Source: Authors' elaboration

The third scenario (il cattivo) would be an intense and lengthy struggle over advantages of cutting-edge technologies, with more extensive tests of force in local crises or even regional wars. One would testify a growing political and strategic animosity and "lock-in" of strategic instability. The cause for such instability would be the great powers' efforts to achieve strategic primacy - when one country would enjoy the benefits of being the first mover. Hence, it would be characterized by a never-ending arms race between great powers in weapons and structures related to the third offset strategy technologies. It would be a scenario where great powers spend a great deal of time and resources to surpass the others' developments and continue to reject strategic arms control. In such a case, it would probably be an unstable system with a higher risk of breaking the nuclear threshold either by accident or intentionally. Bas and Coe $(2012,652)$ argue that "states' inability to commit to not taking advantage of their new weapons can, under certain conditions, lead to a preventive war aimed at stopping a state from getting the new technology."

To analyze how the world may get back to a path of strategic stability, it is of the utmost importance to emphasize under what conditions strategic stability arose in the 1970s. Great powers can defect their formal institutional obligations when compliance is no longer convenient and the more informal dimensions of institutionalized behavior change in accordance (Mearsheimer 1994). Hence, institutions are subject to "restructuring or abandonment with each shift in the distribution of state power and interests" (Duffield 2006, 640). Coe and Vaynman (2020) show that countries face a trade-off between transparency and security when entering formal agreements. According to the authors, "transparency might also reveal vulnerabilities that could be exploited by the first side in an arms race or war" (Coe and Vaynman 2020,353). 
It will take an undefined amount of time for the development of these new technologies and weapons to result in material effects. Moreover, there is a curvilinear line in the utility of these weapons - they will bring significant advantage only up to a certain point. After that, a possible scenario would probably resemble the one where the material component of strategic stability was attained in the 1960s and 1970s. Hence, these states will likely possess the amount of surviving weapons needed to inflict unacceptable damage in a retaliatory strike in case of a first strike.

That is why the second scenario, an ugly one for sure, seems to be the most plausible. Renewed arms limitation talks and treaties depend on great powers renouncing the efforts of undermining MAD. Although power and technological diffusion did not lead to gross power deconcentration towards other countries, China and Russia could bear the logistical and organizational costs for competing with the U.S. and have kept so far an assured retaliatory capability. Furthermore, Russia and China only need to find relatively low-cost and technically viable countervails to the Pentagon's latest weapon systems to pose a challenge to U.S. forward forces operating in Asia and Western Europe, without the need to achieve parity (or symmetry) with the United States (Johnson 2018). All such developments go contrary to Wohlforth's (1999) expectations that no other countries would be capable of sustaining the costs of competing with the United States. The consequences of the balance of power dynamics are not inexorable, but changing a path already taken is not easy either. Eventually, great powers may agree on treaties to regulate behavior, limit weapons in cyberspace and outer space, or restrict hypersonic and other conventional weapons classes (Speier et al. 2017).

Finally, the future of strategic stability depends on the U.S.'s financial intensity and organizational capital required to adopt military innovations. Likewise, the future will depend on China and Russia's responses, resources, and counter-innovations. Hence, the patterns of challenge, strategic response, and adaptation will continue to shape the direction and character of long-term strategic competition where peer competitors cannot outspend the other (Biddle and Oelrich 2016; Kashin and Raska 2017).

\section{Conclusion}

The two primary components of strategic stability in the first nuclear age - MAD and arms limitation - may also be the second nuclear age pillars. However, strategic stability depends on the great powers' interactions and perceptions regarding costs, risks, utility, and doctrines. The end of the legacy that resulted from the 2001 critical juncture will only happen after a considerable amount of time and effort. As Anichkina et al. $(2018,271)$ stressed, "both parties need to find mutually acceptable solutions to the challenges of reconciling nuclear deterrence and arms control." The INF Treaty's demise needs to be understood in the broader context of the strategic arms regime's gradual erosion. Hence, the five-year extension of New START is a 
positive step, but it is far from a new regime, even if one ignores China's absence and focuses only on US-Russian relations. Although Biden's presidency may reduce current tensions and animosities, such a course of action is far from settled and it does not automatically restore the strategic equilibrium.

For now, no one seems willing to incur the risk of falling behind. There are strong indications of the world being characterized by renewed great power competition. That means that other issues remain on the security agenda, although with a distinctive character. For example, it takes an entirely different budget destination and force structure to fight counterinsurgency and prepare for a large-scale war against a peer competitor. Technological advances are not enough. Due to war attrition, mass still matters, and politics continues to direct the uses of force. In short, there is no silver bullet to solve all security problems and dynamics, and there will be no quick and decisive victories. Politics over time means institutions and institutionalized interactions.

Anarchical as it is today, international systems are made of layers of institutions and networked actors. Strategic stability is one such institutional complex. Under specific conditions, it contributes to ease anarchy. This article explains strategic stability within a path dependence framework that does not decouple institutions from power politics. Lobell and Nicholson $(2019,142)$ view international institutions as "non-material structural modifiers." They may not be sufficient to radically change the structural fabric of international politics. However, institutions with strong interactional dynamics can make it more or less conflictive.

Since the critical juncture of 2001, strategic instability has been the legacy reproduced. The status quo ante (strategic stability) has been threatened by the United States' efforts to deny other countries a retaliatory strike capacity and achieve nuclear primacy. Russia and China's reactions contributed to reinforce the instability path. Trump's presidency has promoted it more explicitly and bluntly due to its ideology. For now, it is possible and even more probable that instability will rise and intensify since each great power will try to benefit the most from this window of opportunity for change. Such a system configuration would resemble Mearsheimer's (2001) unstable multipolarity, but without his unrealistic belief regarding the role the U.S. plays.

Washington's behavior since 2001 has been mostly revisionist and offensive as one would expect from a tragic great power with excessive power compared with others (Jervis 2006). Hence, our analysis makes a significant contribution regarding cases in which reactive sequences are driven by winners of an institution, rather than from its losers. Such a conclusion contradicts the most common expectations that reactive sequences are driven "by those whose normative expectations are violated rather than affirmed by the workings of an institution" (Hanrieder and Zürn 2017, 100).

Finally, due to the long-standing difficulty of denying other great powers the capacity of launching a retaliatory strike, combined with less polarized elite dispositions towards pressing global challenges, a more realistic and pragmatic approach may emerge among the great powers. As Gray (1999) emphasizes, there is no strong reason to believe that great powers will behave in ways radically different from times past. Unfortunately, stability is often narrowly considered in 
technological or operational terms. Nevertheless, politics lies at the heart of stability, not weapons or operational plans (Lonsdale 2019). Although it is not possible to estimate when precisely it will happen, the costs and risks of such intense military competition may force the great powers to negotiate new ways of stabilizing their respective security without rendering the world more insecure than it is today.

\section{Acknowledgements}

Funding information: Conselho Nacional de Desenvolvimento Científico e Tecnológico (CNPq) grant number 312939/2020-5, and Coordenação de Aperfeiçoamento de Pessoal de Nível Superior (CAPES) grant number 88882439831/2019-01.

\section{References}

Acton, J.M. Silver Bullet? Asking the Right Questions About Conventional Prompt Global Strike. Washington: Carnegie, 2013.

Acton, J.M. Entanglement: Russian and Chinese Perspectives on Non-Nuclear Weapons and Nuclear Risks. New York: Carnegie, 2017.

Anichkina, T., A. Péczeli and N. Roth. "The future of US-Russian nuclear deterrence and arms control." Bulletin of the Atomic Scientists 73, no. 4 (2018): 271-278. doi: https://doi.org/10.1080/00963402.2017.1338046

Bas, M.A., and A.J. Coe. "Arms Diffusion and War." Journal of Conflict Resolution 56, no. 4 (2012): 651-674. doi: https://doi.org/10.1177/0022002712445740

Baylis, J. "Arms Control and Disarmament." In Strategy in the Contemporary World: an Introduction to Strategic Studies, edited by J. Baylis, J. Wirtz, E. Cohen and C. Gray, 183-207. New York: Oxford University Press, 2002.

Bennett A., and C. Elman, "Case Study Methods." In The Oxford Handbook of International Relations, edited by C. Reus-Smit and D. Snidal, 499-517. Oxford University Press, 2008.

Betts A., and P. Collier. Refuge: Transforming a Broken Refugee System. London: Allen Lane, 2017.

Betts, R.K. "A Nuclear Golden Age? The Balance before Parity." International Security 11, no. 3 (1986): 3-32. doi: https://doi.org/10.2307/2538883

Biddle, S., and I. Oelrich. "Future Warfare in the Western Pacific" International Security 41, no. 1 (2016): 7-48. doi: https://doi.org/10.1162/ISEC_a_00249

Bose, M., et al. American Government: Institutions and Policies. Boston: Cengage Learning, 2019. Brown, S. “The Trump Administration's Nuclear Posture Review” Journal for Peace and Nuclear Disarmament 1, no. 2 (2018): 268-280. doi: https://doi.org/10.1080/25751654.2018.1494092 
Bruusgaard, K.V. “Russian Strategic Deterrence.” Survival 58, no. 4 (2016): 7-26. doi: https://doi.org/10.1080/00396338.2016.1207945

Capoccia G., and D. Kelemen. "The Study of Critical Junctures." World Politics 59, no. 3 (2007): 341-369. doi: https://doi.org/10.1017/S0043887100020852

Carson A., and A. Thompson. "The Power in Opacity." In International Institutions and Power Politics, edited by A. Wivel and T.V. Paul, 101-115. Washington: Georgetown University Press, 2019.

Cepik, M., and C. Ambros. "Intelligence, Crisis, and Democracy" Intelligence and National Security 29, no. 4 (2014): 523-551. doi: https://doi.org/10.1080/02684527.2014.915176 Cepik, M., and G.S. Santos. "O conceito de Ataque Global Imediato" Carta Internacional 12, no. 3 (2017): 5-29. doi: https://doi.org/10.21530/ci.v12n3.2017.684

Chase, M.S. "Chinese Views on the 2018 Nuclear Posture Review, and Their Implications." China Brief 18, no. 4 (2018): 11-14. https://jamestown.org/program/chinese-views-on2018-npr/

Chase, M.S., C.L. Garafola and N. Beauchamp-Mustafaga. "Chinese Perceptions of and Responses to US Conventional Military Power.” Asian Security 14, no. 2 (2018): 136-154. doi: https://doi.org/10.1080/14799855.2017.1301931

Cimbala S.J., and R.N. McDermott. "A New Cold War?” Comparative Strategy 34, no. 1 (2015): 95-111. doi: https://doi.org/10.1080/01495933.2015.994405

Cimbala, S. J. “The Trump Nuclear Posture Review.” Strategic Studies Quarterly 12, no. 2 (2018): 9-16. https://www.jstor.org/stable/26430814

Coe, A.J., and J. Vaynman. "Why Arms Control Is So Rare.” American Political Science Review 114, no. 2 (2020): 342-355. doi: https://doi.org/10.1017/S000305541900073X Collier D., and R. Collier. Shaping the Political Arena: critical junctures, the labor movement, and regime dynamics in Latin America. Princeton University Press, 1991.

Dombrowski, P. America's Third Offset Strategy. Singapore: RSIS Policy Report, 2015. Duffield, J.S. "International Security Institutions: Rules, Tools, Schools, or Fools?” In The Oxford Handbook of Political Institutions, edited by R.A.W. Rhodes, S. Binder and B.A. Rockman, 633-653. Oxford University Press, 2006.

Dvorkin, V. "Deterrence and Strategic Stability." In Nuclear Reset, edited by A. Arbatov and V. Dvorkin, 25-46. Moscow: Carnegie Moscow, 2012.

Fioretos, O. "Historical Institutionalism in International Relations." International Organization 65, no. 2 (2011): 367-99. doi: https://doi.org/10.1017/S0020818311000002 Fioretos, O. "Institutions and Time in International Relations." In International Politics and Institutions in Time, edited by O. Fioretos, 3-36. Oxford University Press, 2017. Ford, C.A. "Arms Control and Strategic Stability." In Strategic Stability: contending interpretations, edited by E. A. Colby and M. S. Gerson, 201-270. Carlisle: U.S. Army War College Press, 2013. 
Freyberg-Inan, A. “The Dynamic Relations between Power Politics and Institutionalization” In International Institutions and Power Politics, edited by A. Wivel and T.V. Paul, 185-196. Washington: Georgetown University Press, 2019.

Garcia, Z. "Strategic Stability in the Twenty-first Century." Comparative Strategy 36, no. 4 (2017): 354-365. doi: https://doi.org/10.1080/01495933.2017.1361207

Ghoshal, D. "China and the INF Treaty." Comparative Strategy 35, no. 5 (2016): 363-370. doi: https://doi.org/10.1080/01495933.2016.1240982

Glaser, C.L. Rational theory of international politics. Princeton University Press, 2010.

Glaser, C.L., and S. Fetter. "Should the United States Reject MAD?" International Security 41, no. 1 (2016): 49-98. doi: https://doi.org/10.1162/ISEC_a_00248

Gray, C.S. “The Definitions and Assumptions of Deterrence.” Journal of Strategic Studies 13, no. 4, (1990): 1-18. doi: https://doi.org/10.1080/01402399008437428

Gray, C.S. The Second Nuclear Age. Boulder: Lynne Rienner Publishers, 1999.

Greif, A., and D. Laitin. "A Theory of Endogenous Institutional Change." American Political Science Review 98, no. 4 (2004): 633-52. doi: https://doi.org/10.1017/S0003055404041395

Haffa Jr., R.P. “The Future of Conventional Deterrence.” Strategic Studies Quarterly 12, no. 4 (2018): 94-115.

Hanrieder, T., and M. Zürn. “Reactive Sequences in Global Health Governance.” In International Politics and Institutions in Time, edited by O. Fioretos, 93-116. Oxford University Press, 2017.

Harvey, F.P. “The Future of Strategic Stability and Nuclear Deterrence." International Journal 58, no. 2 (2003): 321-346. doi: https://doi.org/10.1177/002070200305800205

IISS. Strategic Survey 2020. London: Routledge, 2020.

Ikenberry, G.J. "The logic of order". In Power, Order, and Change in World Politics, edited by G.J Ikenberry, 83-106. Cambridge University Press, 2014.

Ikenberry, G.J. “The end of liberal international order?” International Affairs 94, no. 1 (2018): 7-23. doi: https://doi.org/10.1093/ia/iix241

Ivanov, I. “The Missile-Defense Mistake." Foreign Affairs 79, no. 5 (2000): 15-20. doi: https://doi.org/10.2307/20049885

Jervis, R. "Arms Control, Stability and Causes of War." Political Science Quarterly 108, no. 2 (1993): 239-253. doi: https://doi.org/10.2307/2152010

Jervis, R. "The remaking of a unipolar world." The Washington Quarterly 29, no 3 (2006): 5-19. doi: https://doi.org/10.1162/wash.2006.29.3.5

Johnson, J.S. "China's vision of the future network-centric battlefield: Cyber, space and electromagnetic asymmetric challenges to the United States.” Comparative Strategy 37, no. 5 (2018): 373-390. doi: https://doi.org/10.1080/01495933.2018.1526563

Kashin, V., and M. Raska. Countering the U.S. Third Offset Strategy. Singapore: RSIS Policy Papers, 2017.

Keohane, R.O. International Institutions and State Power. Boulder: Westview Press, 1988. 
Keohane, R.O. "Observations on the Promise and Pitfalls of Historical Institutionalism in International Relations." In International Politics and Institutions in Time, edited by O. Fioretos, 321-336. Oxford University Press, 2017.

Koblentz, G.D. Strategic Stability in the Second Nuclear Age. New York: CFR, 2014. Kokoshin, A.A. Ensuring Strategic Stability in the Past and Present. Cambridge, MA: Belfer Center for Science and International Affairs, 2011.

Kroenig, M. The Logic of American Nuclear Strategy. New York: Oxford University Press, 2018. Lieber, K.A., and D.G. Press. "The End of MAD? The Nuclear Dimension of U.S. Primacy." International Security 30, no. 4 (2006): 7-44. doi: https://doi.org/10.1162/isec.2006.30.4.7

Lieber, K.A., and D.G. Press. "The New Era of Counterforce Technological Change and the Future of Nuclear Deterrence." International Security 41, no. 4 (2017): 9-49. doi: https://doi.org/10.1162/ISEC_a_00273

Lobell, S.E., and B. Nicholson. "Structural Modifiers, the Non-Proliferation Treaty Regime, and Fostering a Less Competitive International Environment." In International Institutions and Power Politics, edited by A. Wivel and T.V. Paul, 137-148. Washington: Georgetown University Press, 2019.

Longhurst, K. "Why aren't the Germans debating the draft?" German Politics 12, no. 2 (2003): 147-165. doi: https://doi.org/10.1080/09644000412331307614

Lonsdale, D.J. “The 2018 Nuclear Posture Review?” Comparative Strategy 38, no. 2 (2019): 98-117. doi: https://doi.org/10.1080/01495933.2019.1573074

Mahoney, J. "Path Dependence in Historical Sociology." Theory and Society 29 (2000): 507-548. doi: https://doi.org/10.1023/A:1007113830879

Martins, J., and Cepik, M. "Defesa Nacional Antimíssil dos Estados Unidos: a lógica da preempção e suas implicaçóes internacionais.” In Politicas de Defesa, Inteligência e Segurança, edited by C.S. Arturi, 14-47. Porto Alegre: Editora da UFRGS, 2014. Mearsheimer, J.J. “The False Promise of International Institutions.” International Security 19, no. 3 (1994): 5-49. doi: https://doi.org/10.2307/2539078

Mearsheimer, J.J. The Tragedy of Great Power Politics. New York: Norton, 2001.

Naylor, J. L. “The third nuclear age.” Comparative Strategy 38, no. 4 (2019): 276-288. doi: https://doi.org/10.1080/01495933.2019.1633185

North, D. Instituciones, Cambio Institucional y desempeño Económico. México: Fondo de Cultura Económica, 1993.

O’Rourke, R. Renewed Great Power Competition. Washington: Congressional Research Service Report 43838, 2019.

Onuf, N.G. Making Sense, Making Worlds. New York: Routledge, 2013.

Péczeli, A. “The Trump Administration's Nuclear Posture Review.” Journal for Peace and Nuclear Disarmament 1, no. 2 (2018): 238-255. doi: https://doi.org/10.1080/25751654.2018.1530741 Peters, R., J. Anderson and H. Menke. "Deterrence in the 21 st Century." Strategic Studies Quarterly 12, no. 4 (2018): 15-43. https://www.jstor.org/stable/26533613 
Pierson, P. "Increasing Returns, Path Dependence, and the Study of Politics." The American Political Science Review 94, no. 2 (2000): 251-267. doi: https://doi.org/10.2307/2586011

Rixen, T., and A. Viola. "Historical Institutionalism and International Relations: Towards Explaining Change and Stability in International Institutions." In Historical Institutionalism and International Relations, edited by T. Rixen, L.A. Viola and M. Zürn, 3-34. Oxford University Press, 2016.

Rojansky, M. "Russia and Strategic Stability." In Strategic Stability: contending interpretations, edited by E. A. Colby and M. S. Gerson, 295-342. Carlisle: U.S. Army War College Press, 2013.

Sapolsky, H., E. Gholz and C. Talmadge. US Defense Politics: The Origins of Security Policy. New York: Routledge, 2008.

Schoemaker, P. "How historical analysis can enrich scenario planning." Futures and Foresight Science 2, no. 3-4 (2020): e35. doi: https://doi.org/10.1002/ffo2.35

Speier, R.H., et al. Hypersonic Missile Nonproliferation. Santa Monica: RAND Corporation, 2017.

Thelen, K. "Historical Institutionalism in Comparative Politics." Annual Review of Political Science 2 (1999): 369-404. doi: https://doi.org/10.1146/annurev.polisci.2.1.369

Trenin, D. Strategic Stability in the Changing World. Moscow: Carnegie Moscow, 2019.

United States of America. Nuclear Posture Review. Washington-D.C., Office of the Secretary of Defense, 2018.

Wang, R. "Making Sense of Chinese Reactions to the US 2018 Nuclear Posture Review" The Diplomat, February 27, 2018, https://thediplomat.com/2018/02/making-sense-ofchinese-reactions-to-the-us-2018-nuclear-posture-review

Weyland, K. “Toward a New Theory of Institutional Change.” World Politics 60, no. 2 (2008): 281-314. doi: https://doi.org/10.1353/wp.0.0013

Wilkening, D. "Hypersonic Weapons and Strategic Stability." Survival 61, no. 5 (2019): 129-148. doi: https://doi.org/10.1080/00396338.2019.1662125

Wivel, A., and T.V. Paul, "Exploring International Institutions and Power Politics." In International Institutions and Power Politics, edited by A. Wivel and T.V. Paul, 3-19. Washington: Georgetown University Press, 2019.

Wohlforth, W.C. “The Stability of a Unipolar World.” International Security 24, no. 1 (1999): 5-41. https://www.jstor.org/stable/2539346

Young, O.R. “The Rise and Fall of International Regimes.” International Organization 36, no. 2 (1982): 277-297. doi: https://doi.org/10.1017/S0020818300018956 